\title{
Detcetion Of Bacterial Contamination Of Drinking Water In The Right Side Of Mosul City By Multiple Tubes Fermentation Technique.
}

\author{
Musaab O. Hamad Al- Ballo \\ General Director Of Education In \\ Nineveh
}

\author{
Adeba Y. Sharif AL-Nua'aman \\ University Of Mosul \\ College Of Science \\ shareefadeeba@yahoo.com
}

\section{Received Accepted \\ 27/09/2018 03/12/2018}

\begin{abstract}
This study aimed to investigate bacterial contamination of drinking water in the right side of Mosul city using multiple tubes fermentation technique, depending on total coliform count as an indicator, this study takes seven months started from December, 2017 to June, 2018.

Three hundered fifteen smples were collected from water purification plants and 12 quarters in the right side of Mosul city include (Msherfa, 17-Tamoz, Al-refaee, Talalromman, Al-moa'alemen, Al-shohada'a, Nabls, Al-resala, Al-a'amel, Al-tayaran, Wadi hajar and Al-mansour).

The results showed contaminate of water in purification plants during April and May only while the contamination wase in all study months of the water reaching consumers with a rate reaching $40.5 \%$ of total samples and the highest was in Al-refaee quarter $(71.4 \%)$ whereas the lowest reached $14.3 \%$ in Nabls quarter, the results also showed variations in the contamination during the study monthes, it's highest in May as it reached $83.3 \%$ whereas the lowest was in January as it reached $16.7 \%$. The results of chlorine concentration test showed that the residual chlorine was less than the accepted levels in some quarters formed a ratio reached $32.1 \%$, while it was higher than the accepted level at a ratio of $2.4 \%$, whereas the residual chlorine in $65.5 \%$ from total samples was within the accepted level. In this study we isolate and identificate some of the contaminating bacteria such as Escherichia coli , Klebsiella pneumoniae,

Enterobacter cloacae, Enterobacter aerogenes, Proteus mirabilis, Citrobacter freundii and Salmonella typhi, Escherichia coli forming the higher rate $40.8 \%$ whereas the lower was Citrobacter freundii $4.1 \%$. Pseudomonas aeruginosa was also isolated in this study at $14.3 \%$ of the total isolated bacteria.
\end{abstract}

Key words: water pollution, total coliform, MPN. 


\section{التحري عن التلوث الجرثومي لمياه الثرب في الساحل الأيمن من مدينة الموصل باستعمال طريقة الأنابيب التخمرية المتعددة.}

\author{
أ. د. اديبة يونس شريف النعمان \\ جامعة الموصل / كلية العلوم
}

مصعب عبيد حمد البلو

مديرية تربية نيوى

$$
\text { تاريخ الاستلام } \quad \text { 2018/09/27 }
$$

\section{الخلاصة}

اجريت هذه الدراسة بهدف التحري عن التلوث الجرثومي لمياه الثرب في الساحل الأيمن من مدينة الموصل

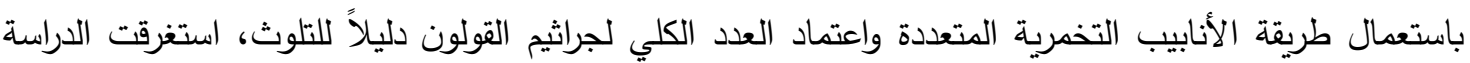
سبعة اشهر ابتدأت في كانون الأول عام 2017 ولغاية حزيران عام 2018 جمعت خلادلها 315 عينة موزعة بالتساوي (بمعدل 21 عينة من كل منطقة) على ثلاث مشاريع لتصفية المياه و12 حياً سكنياً تجهز من هذه

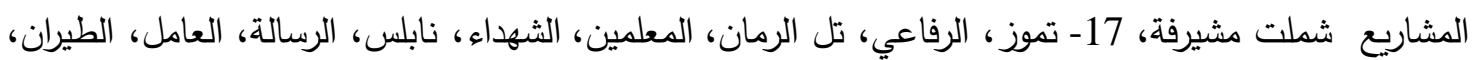

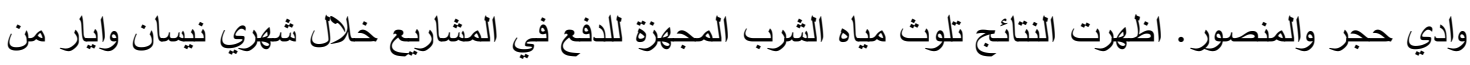
فترة الدرسة اما في المناطق السكنية فقد اظهرت النتائج تلوث مياه الشرب في جميع اشهر الدراسة ولجميع الأحياء، اذ تراوحت نسب الفشل بين اعلى نسبة بلغت 71.4\% في حي الرفاعي وادناها في حي نابلس اذ بلغت 14.3\%، واظهرت النتائج اختلاف نسب الفشل خلال اشهر الدراسة، اذ بلغت اعلاها 83.3\% وكانت فراعي في شهر أيار ، فيما كانت ادناها في شهر كانون الثاني اذ بلغت 16.7\% وأظهرت نتائج فحص الكلور ان تركيز الكلور في

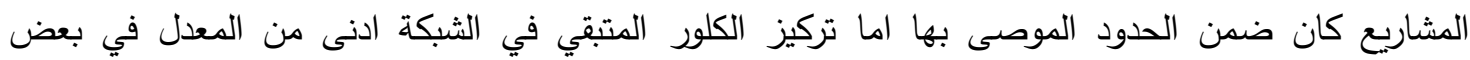
المناطق شكلت نسبة 32.1\% بينما كان اعلى من الحدود المسموح بها في مناطق اخرى شكل شكلت نسبة بلغت فئت

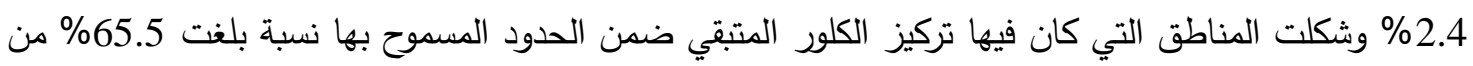

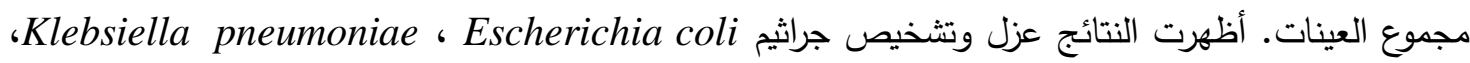
Citrobacter ‘Proteus mirabilis ‘Enterobacter aerogenes ‘Enterobacter cloacae Escherichia Sseudomonas aeruginosa SSalmonella typhi freundii Citrobacter freundii أعلى نسبة إذ بلغت 40.8\% من مجموع الجراثيم المعزولة بينما كانت جرثومة

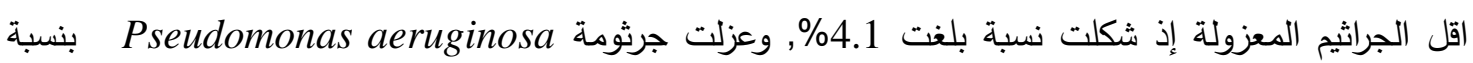




\section{1- المقدمة Introduction}

يعد التلوث الجرثومي للمياه المعدَّة للإستعمالات البشرية من اخطر حالات التلوث لعلاقته المباشرة

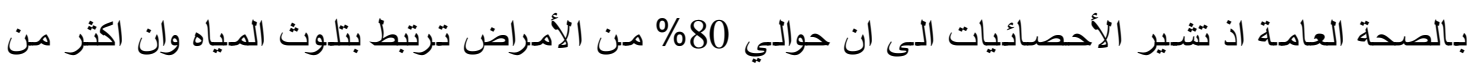
تلث الوفيات في الدول النامية تتتج عن استعمال المياه الملوثة [1,2]. لعب تلوث مياه الثرب في السنوات الأخيرة دوراً كبيرا في انتشار الأوبئة الخطيرة كالتايفوئيد والأسهال الذي اودى بحياة الملايين من الأطفال دون سن الخامسة من العمر [3], وتعد الجراثيم السبب الرئيس في مثل هذه

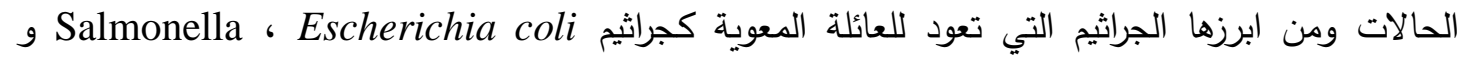
فضسلاً عن جرثومة Vibrio cholera المسببة لوباء الكوليرا الذي ينتشر بين فترة واخرى في العديد

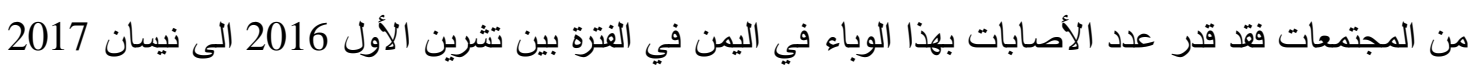

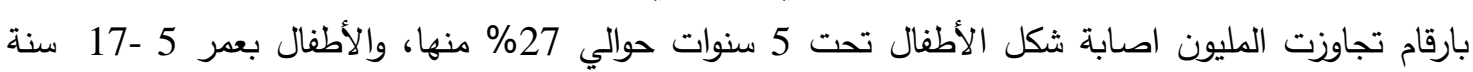

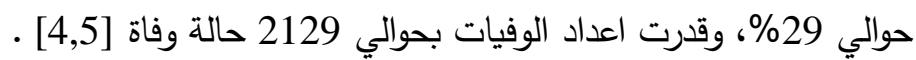
ان الطريقة الوحيدة للتأكد من وجود او خلو مياه الثرب من الجراثيم هي بفحص لفول عينات منها للتأكد من مدى مطابقتها للمواصفات المحددة من قبل المنظمات العالمية كمنظمة الصحة العالمية ووكالة حماية البيئة[6]، مناه ان الكثف عن كل هذه الجراثيم المرضية عملية تستغرق وقتاً طويلا وتتطلب جهدا كبيرا لذا يصار الى الأعتماد

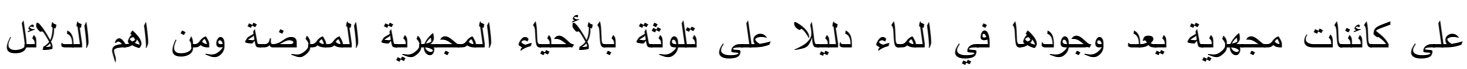
الجرثومية مجموعة القولونيات الكلية Total coliform التي تعرف على انها جراثيم عصوية، لاهوائية اختيارية، سالبة لصبغة كرام، غير مكونة للأبواغ، تخمر سكر اللاكتوز عند درجة حرارة 35-37 مُ منتجة للحامض والغاز خلال 24-24 ساعة وتضم انواعاً مثل Enterobacter spp. ،Klebsiella spp. ،Escherichia coli ، [7,8,9] Serattia spp. Citrobacter spp. تستعمل العديد من الطرائق للكثف عن هذه الدلائل منها ما تعتمد على الأوساط الزرعية ، اوباستعمال طرائق

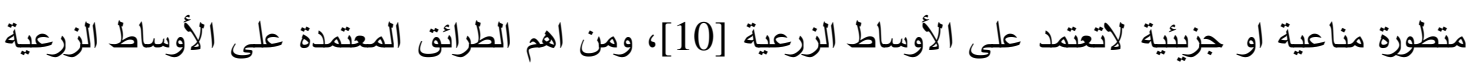

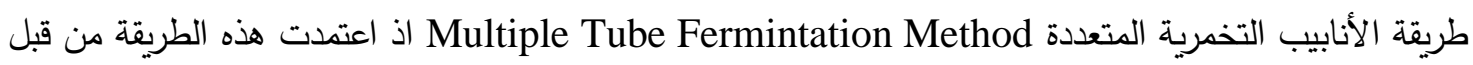
US Environmental Protection الهيئات المتخصصة بفحوصات المياه مثل الوكالة الأميركية لحماية البيئة American Public Health Association (APHA) ورابطة الصحة الأميركية Agency (US-EPA) للكثف عن جراثيم القولون الكلية والبرازية وجرثومة E. coli والمكورات السبحية البرازية [10,11] فيطة ويمكن

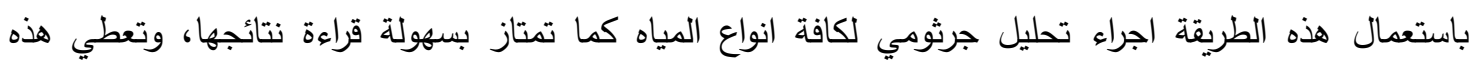

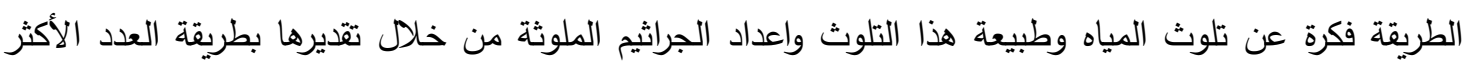

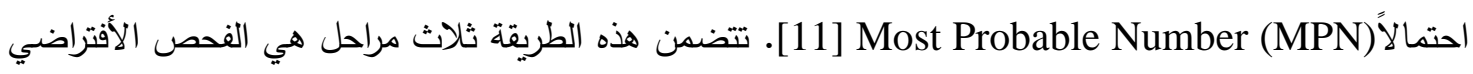
Presumptive test خلالها التحري عن التلوث الجرثومي في عينات الماء المراد فحصها وذلك بتلقيح انابيب اختبار حاوية على الأوساط الزرعية الملائمة بحجوم محددة من العينة وبعد انتهاء فترة التحضين تسجل النتائج، يستدل على وجود التلوث بتكون الغاز الذي يتجمع في انابيب صغيرة توضع بثكل مقلوب داخل انابيب الوسط الزرعي تعرف

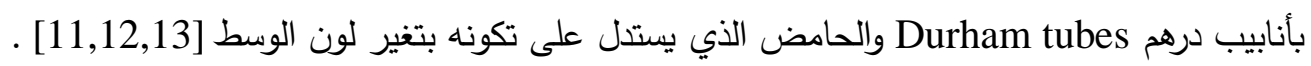


تعاني مدينة الموصل خاصة الساحل الأيمن من دمار طال البنية التحتية الخاصة بتجهيز المياه الصالحة للشرب ولذا فقد جاءت هذه الدراسة بهدف التحري عن التلوث الجرثومي لمياه الثرب في الساحل الأيمن في مدينة الموصل باستعمال طريقة الأنابيب التخمرية المتعددة.

Materiales and methods 2- المواد وطرائق العمل 1-2 الأوساط الزرعية المستعملة: استعملت الأوساط الزرعية المبينة في الجدول (2-1) اذ حضرت الأوساط وضبطت قيم الأس الهيدروجيني وعقدت حسب تعليمات الشركة المصنعة.

الجدول (1-2) الأوساط الزرعية المجهزة تجاريا المستعملة في الدراسة.

\begin{tabular}{|c|c|c|}
\hline الشركة المصنعة الشعة & 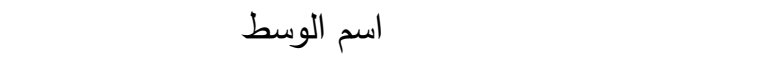 & ت \\
\hline Lab M & مرق الماكونكي MacConkey broth احادي التركيز & 1 \\
\hline Lab M & مرق الماكونكي MacConkey broth مضاعف التركيز & 2 \\
\hline Lab M & MacConkey agar اكار الماكونكي & 3 \\
\hline Scharlau & اكار الأيوسين المثيلين الأزرق E. M. B. Agar & 4 \\
\hline Accumix & Nutrient Agar & 5 \\
\hline Accumix & المرق المغذي Nutrient broth & 6 \\
\hline
\end{tabular}

2-2

اختير 12 حياً سكنياً من احياء الساحل الأيمن من مدينة الموصل تجهز بماء الثرب من ثلاثة مشاريع لتصفية المياه تقع على نهر دجلة هي مشروع الأيمن الموحد، مشروع الأيمن الجديد ومشروع ماء الغزلاني اختيرت

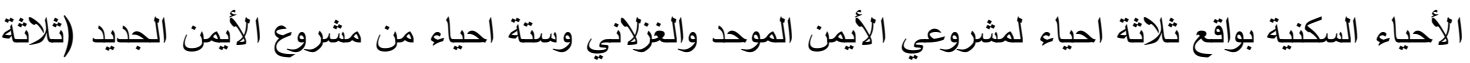
احياء لكل خط)، تبعد هذه الأحياء بمسافات مختلفة عن المشروع او الخط المجهز لهاء بحيث يمثل اول الألئ الأحياء

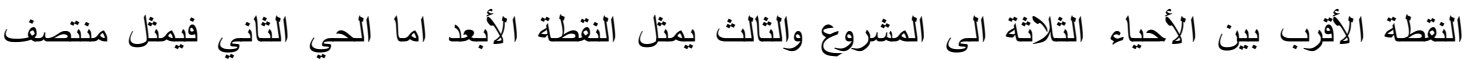

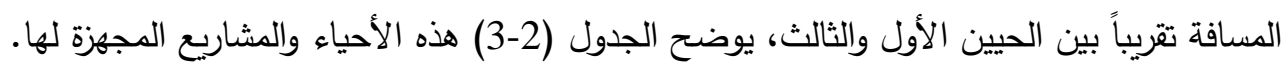

الجدول (2-2) الأحياء السكنية قيد الدراسة والمشاريع المجهزة لها.

\begin{tabular}{|c|c|c|c|}
\hline الأحياء التي يجهزها & موقع المشروع & اسم المشروع & ت \\
\hline مشيرفة -17- تموز - الرفاعي & الضفة اليمنى لنهر دجلة & الأيمن الموحد & 1 \\
\hline 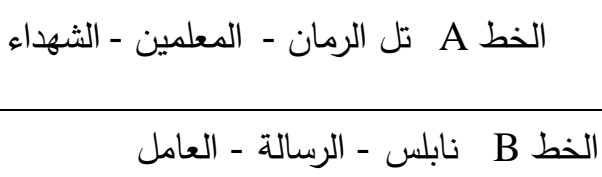 & الضفة اليمنى لنهر دجلة قرب & الأيمن الجديد & 2 \\
\hline
\end{tabular}




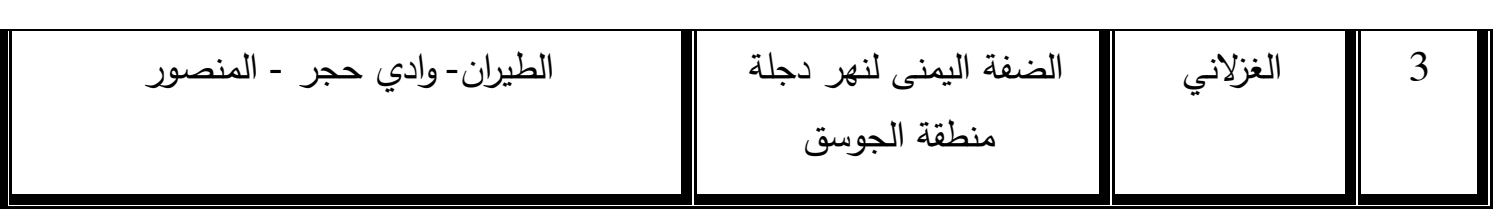

3-2 جمع العينات

جمعت في هذه الدراسة 315 عينة من المشاريع والأحياء السكنية قيد الدراسة بواقع ثلاث عينات منفصلة لكل منطقة في الثهر الواحد ولمدة سبعة اشهر ابتدأت في شهر كانون الأول من العام 2017 وانتهت في شهر فئر حزيران من العام 2018.

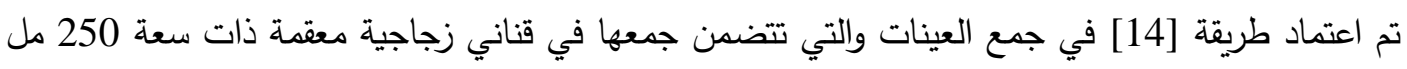
حاوية على 0.2 مل من محلول ثايوسلفات الصوديوم عينة الماء، جمعت العينات في الصباح الباكر وذلك عن طريق تنظيف الحنفية التي تجهز المنزل بماء الأسالة الرئيسي بصورة جيدة من المواد المتكلسة ثم عقدت بطريقة التلهيب الكحولي وفتحت الحنفية على سعتها لمدة 23 دقائق للتخلص من المياه الراكدة، اخذت كمية قليلة من الماء لقياس تركيز الكلور المتبقي في العينة واغلقت الحنفية، عقدت الحنفية مرة ثانية ثم فتحت واخذت العينة للفحص الجرثومي اذ ملئت القنينة المعقدة وذلك بفتح غطائها قرب الحنفية مع مراعاة ترك فراغ في القنينة لرج النموذج من اجل توزيع الجراثيم بصورة متجانسة، سجلت

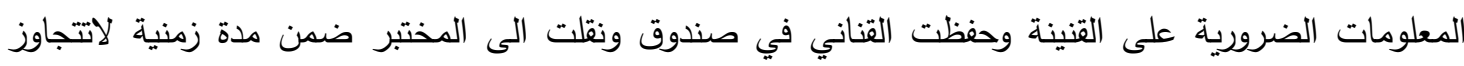
ثلاث ساعات واجريت عليها الفحوصات اللازمة في المختبر . 4-2 قياس تركيز الكلور المتبقي في عينات المياه المدروسة

تم قياس تركيز الكلور المتبقي في مكان اخذ العينة باستعمال جهاز فحص الكلورين المتبقي Chlorometer

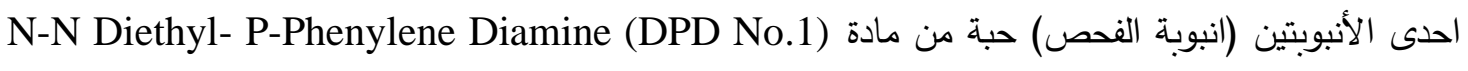
اما الأنبوبة الأخرى فتركت بدون اضافة (للسيطرة)، وضعت الأنبوتان في الجهاز وتم تدوير قرص الألوان المثبت

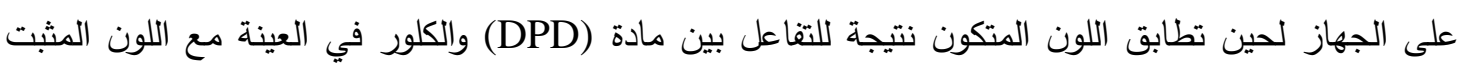

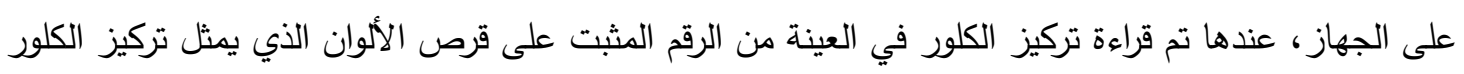

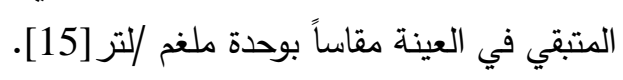

2-5 اجنراء الفحص الجرثومي

استعملت طريقة الأنابيب التخمرية المتعددة Multiple Tubes Fermintation Method

$$
\text { الفصص الجرثومي وتتضمن هذه الطريقة ثلاث مراحل: }
$$

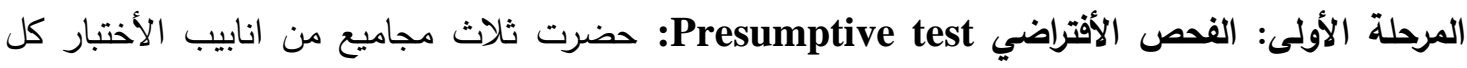
مجموعة تضم ثلاثة انابيب اختبار ذات سعة 25 مل، وضع في كل انبوبة من هذه الأنابيب انبوبة درهم

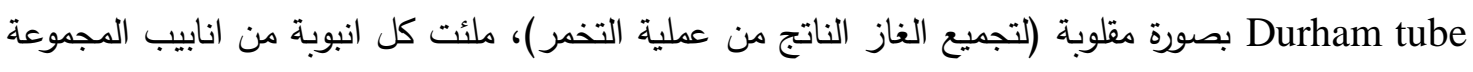
الأولى بـ 10 مل من وسط مرق الماكونكي MacConkey broth مضاعف التركيز ، اما المجموعتان الثانية والثالثة فملئت كل انبوبة فيهما بـ 10 مل من وسط مرق الماكونكي احادي التركيز، سدت فوهات الأنابيب بقطعة

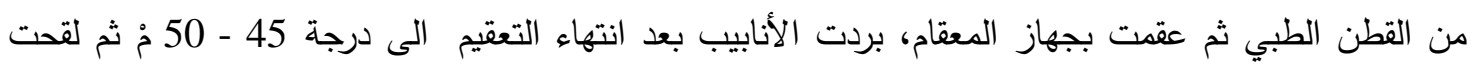

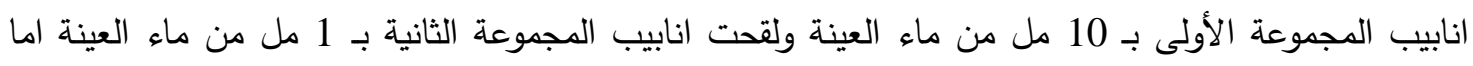


المجموعة الثالثة فلقحت بـ 0.1 مل من ماء العينة، حضنت الأنابيب بعد ذلك في الحاضنة بدرجة حرارة 37 م لمدة 24-48 ساعة ثم سجلت النتائج بعد انتهاء فترة التحضين، عدت النتيجة موجبة (حدوث التخمر بسبب وجود

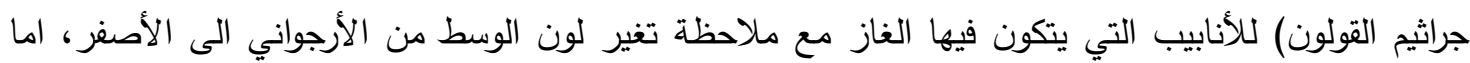

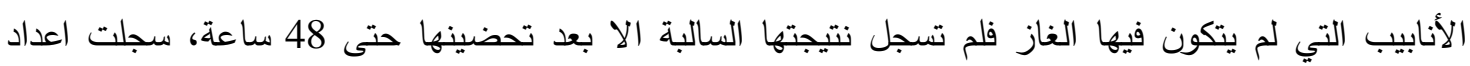
الأنابيب التي حدث فيها تخمر في المجاميع الثلاث وقورنت النتائج مع جداول معينة تسمى جداول الأحتمالية

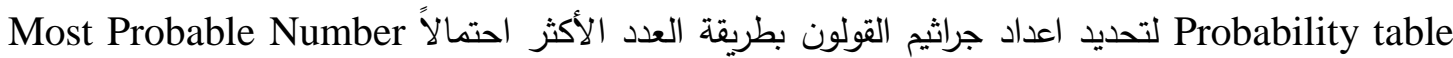
(MPN)، ثبت اعداد جراثيم القولون الكلية في 100 مل من العينة، عدت العينة مقبولة اذا كان عدد جراثيم

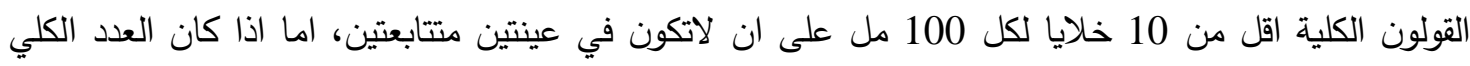
لجراثيم القولون 10 خلايا فاكثر لكل 100 مل فعدت العينة فاشلة. ولغرض تقييم معدل نتائج كل منطقة في الثهر الواحد لوحظت نتائج العينات الثلاثة فاذا كان عدد العينات الفاشلة اثنان اواكثر عدت النتيجة فاشلة لذلك

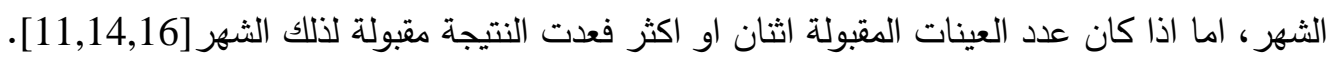
المرحلة الثانية: الفحص التأكيدي Confirmed test: اخذت حملة لقاح باستعمال الناقل ذي العروة Loop من الأنابيب الموجبة في الفحص الأفتراضي ولقح بها وسط مرق الماكونكي ثم حضنت الأنابيب بدرجة حرارة 37

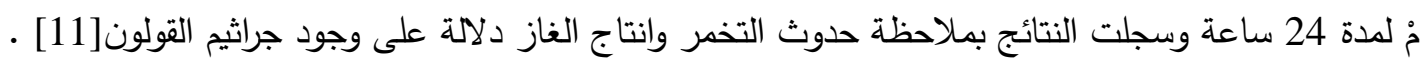
المرحلة الثالثة: الفحص التكميلي Completed test: لقحت اوساط انتخابية صلبة Selective agar: Eosine ووسط اكار الأيوسين مثيلين الأزرق MacConkey agar مثل وسط اكار الماكونكي media methylene blue agar EMB

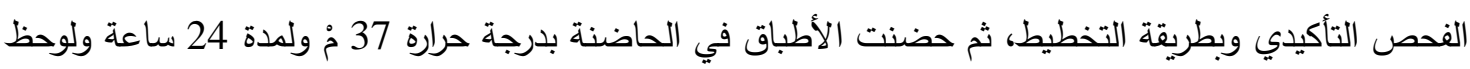

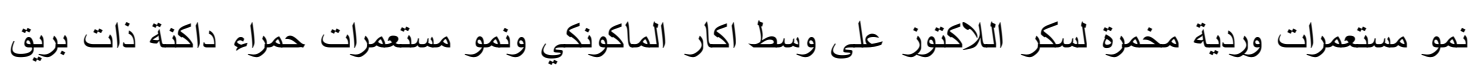
معدني Metalic sheen على وسط EMB تمثل هذه المستعرات جراثيم القولون [14,17] على

\section{3esults and discussion النتائج والمناقشة}

يوضح الجدول(3-1) أعداد جراثيم القولون ونسب الفشل لمشاريع التصفية خلال فترة الدراسة. الجدول (3-1) أعداد جراثيم القولون" /100 مل ونسب الفشل في عينات المياه المفحوصة لمشاريع التصفية قيد

الدراسة في مدينة الموصل بطريقة ونئسن

\begin{tabular}{|c|c|c|c|c|c|c|c|c|}
\hline الفنبة & $\begin{array}{c}\text { حزيران } \\
\text { MPN } \\
\text { ml } \\
100\end{array}$ & $\begin{array}{c}\text { أيار } \\
\text { /MPN } \\
\text { ml } \\
100\end{array}$ & $\begin{array}{c}\text { نيسان } \\
\text { /MPN } \\
\text { ml } \\
100\end{array}$ & $\begin{array}{c}\text { آذار } \\
\text { MPN } \\
\text { ml } \\
100\end{array}$ & $\begin{array}{c}\text { شباط } \\
\text { MPN } \\
\text { ml } \\
100\end{array}$ & $\begin{array}{r}\text { كانون2 } \\
\text { /MPN } \\
100 \mathrm{ml}\end{array}$ & $\begin{array}{c}\text { كانون } \\
\text { /MPN } \\
\mathrm{ml} \\
100\end{array}$ & اليثهرالدراسة \\
\hline 14.3 & 0 & 11 & 2 & 2 & 0 & 0 & 0 & الأيمن الموحد \\
\hline 14.3 & 0 & 3 & 11 & 1 & 0 & 0 & 0 & الأيمن الجديد \\
\hline 14.3 & 0 & 12 & 1 & 0 & 0 & 0 & 0 & يزلاني \\
\hline
\end{tabular}

* تعد العينة فاشلة (غير صالحة للثرب) إذا احتوت على 10 خلايا من جر اثيم القولون/100مل فأكثر 
نلاحظ من الجدول (3-1) أن هناك قصوراً في أداء مشاريع التصفية في بعض اشهر الدراسة إذ كانت أعداد جراثيم القولون في أشهر معينة أعلى من الحدود المسموح بها إلى درجة اعتبرت فيها المياه المجهَزة للمستهلكين فاشلة وغير صالحة للشرب ففي مشروع الأيمن الموحد على سبيل المثال كانت أعداد جراثيم القولون في شهر أيار

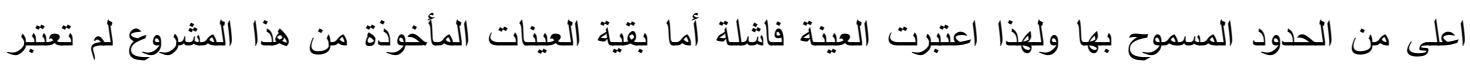
ملوثة لأن اعداد جراثيم القولون فيها كانت منعدمة او ضمن الحدود المسموح بها، وبهذا فإن عينة واحدة أظهرت فثلاً من مجموع سبعة عينات لهذا المشروع شكلت نسبة فثل بلغت 14.3\% وهكذا الحال لبقية المشاريع. يرتبط ظهور حالات التلوث في مشاريع التصفية بأسباب منها كفاءة عملية الترسيب في إزالة المواد العالقة والأطيان من المياه الخام، كما تزيد عمليات الترشيح غير الكفوءة من نسب التلوث إذ أن إنخفاض كفاءة أحواض الترشيح تعد صفة مشتركة بين مشاريع تصفية المياه في محافظة نينوى [18]. وتعد رداءة المياه الخام المجَزة لمشاريع تصفية المياه سبباً في ظهور حالات التلوث الجرثومي والفشل في تجهيز مياه خالية من الجراثيم

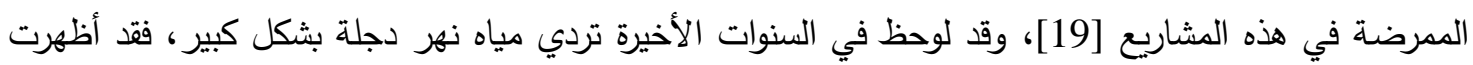

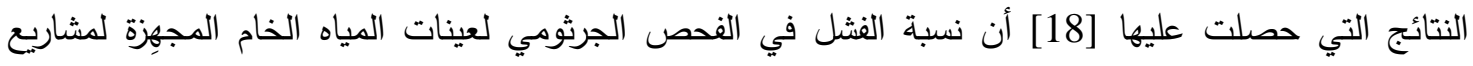
التصفية التي درستها بلغت 66 \% من مجموع العينات المفحوصة. يبين الجدول (3-2) أعداد جراثيم القولون ونسب الفشل خلال اشهر الدراسة، إذ يتبين أن نسب الفشل ظهرت في شهري نيسان وأيار إذ بلغت 33.3 \% و66.6 \% م لكل منهما على التوالي.

الجدول (2-3) أعداد جراثيم القولون* /100 مل ونسب الفشل خلا اشهر الدراسة.

\begin{tabular}{|c|c|c|c|c|c|c|c|}
\hline حزير ان & أيار & نيسان & آذار & شُباط & كانون2 & كانون1 & ثَثرهرالدراسة \\
\hline $\begin{array}{r}\text { MPN } \\
100 \mathrm{ml}\end{array}$ & $\begin{array}{c}\mathrm{MPN} \\
\mathrm{ml} \\
100\end{array}$ & $\begin{array}{r}\text { MPN } \\
100 \mathrm{ml}\end{array}$ & $\begin{array}{r}/ \mathrm{MPN} \\
100 \mathrm{ml}\end{array}$ & $\begin{array}{l}\text { / MPN } \\
100 \mathrm{ml}\end{array}$ & $\begin{array}{c}\text { /MPN } \\
100 \mathrm{ml}\end{array}$ & $\begin{array}{c}\text { /MPN } \\
100 \mathrm{ml}\end{array}$ & \\
\hline 0 & 11 & 2 & 2 & 0 & 0 & 0 & الأيمن الموحد \\
\hline 0 & 3 & 11 & 1 & 0 & 0 & 0 & الأيمن الجديد \\
\hline 0 & 12 & 1 & 0 & 0 & 0 & 0 & الغزلاني \\
\hline 0 & 66.6 & 33.3 & 0 & 0 & 0 & 0 & نسبة الفشل \% \\
\hline
\end{tabular}

* تعد العينة فاثلة (غير صالحة للثرب) إذا احتوت على 10 خلايا من جـ اثيم القولون/100مل فأكثر

إن اعتدال درجات حرارة المياه في هذين الثهرين إلى دعدلات تستطيع الأحياء المجهرية الممرضة في المياه النمو عندها يعطي تفسيراً لظهور هذه الحالات من التلوث [20]. كما تؤدي زيادة نسبة العكورة في المياه

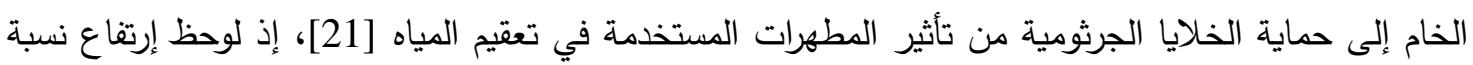
العكورة في مياه نهر دجلة خلا شهر أيار من أشهر الدراسة بشكل عالٍ نتيجة للأمطار الغزيرة التي شهدتها المحافظة في معظم أيام هذا الثهر وبعض أيام شهر نيسان مما زاد من كمية الأطيان والمواد العالقة في النهر لئهر

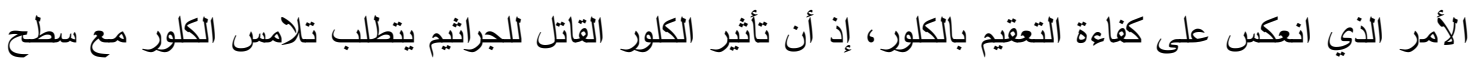


الخلايا الجرثومية مدة لاتقل عن 30 دقيقة [17] وإن هذا التلامس لايحدث في حالة وجود دقائق الطين التي تحتمي بها الخلايا الجرثومية. أظهرت نتائج فحص تركيز الكلور المضاف في المشاريع أن تركيز هذه المادة كان

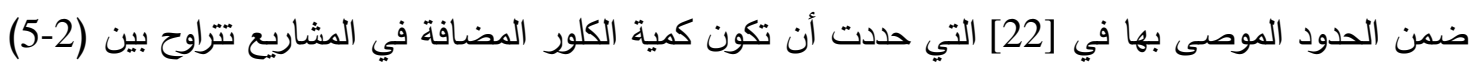
ملغم/ لتر. وعلى الرغم من أن تركيز الكلور ضمن الحدود المسموح بها فقد ظهرت حالات تلوث بجراثيم القولون لارجةٍ عدت معها تلك العينات فاشلة وغير صالحة للشرب، ولعل السبب في ذلك هو كمية الأطيان والمواد العالقة في النهر الأمر الذي انعكس على كفاءة التعقيم بالكلور [17] أوظهور جراثيم مقاومة للكلور المستخدم في التعقيم، إذ عزلت[23] جراثيم مقاومة للكلور من أنظمة مياه الثرب في كندا. يوضح الجدول (3-3) اعداد جراثيم القولون الكلية ونسب الفشل في عنيمة عينات مياه الثرب من الأحياء السكنية قيد الدراسة في الساحل الأيمن من مدينة الموصل وبطريقة العدد الأكثر احتمالاً. الجدول(3-3) اعداد جراثيم القولون الكلية /100 مل ونسب الفشل في عينات مياه الثرب من مناطق الدراسة

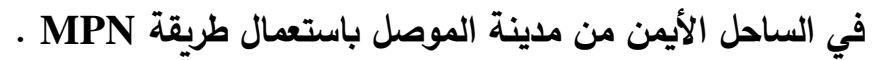

\begin{tabular}{|c|c|c|c|c|c|c|c|c|}
\hline نسبة الفشل لكل & حزيران & أيار & نيسان & آذار & شباط & كانون2 & كانون1 & إلدراسة \\
\hline الدراسة & $\begin{array}{c}/ \mathrm{MPN} \\
\mathrm{ml} \\
100\end{array}$ & $\begin{array}{c}\text { /MPN } \\
\mathrm{ml} \\
100\end{array}$ & $\begin{array}{c}\text { /MPN } \\
\mathrm{ml} \\
100\end{array}$ & $\begin{array}{r}/ \mathrm{MPN} \\
100 \mathrm{ml}\end{array}$ & $\begin{array}{r}\text { MPN } \\
\mathrm{ml} / \\
100\end{array}$ & $\begin{array}{c}\text { /MPN } \\
\mathrm{ml} \\
100\end{array}$ & $\begin{array}{r}\text { /MPN } \\
\mathrm{ml} \\
100\end{array}$ & \\
\hline$\% 42.9$ & 8 & 30 & 15 & 2 & 0 & 3 & 13 & مشيرفة \\
\hline$\% 42.9$ & 9 & 49 & 4 & 8 & 0 & 14 & 14 & 17- تموز \\
\hline$\% 71.4$ & 15 & 57 & 20 & 8 & 3 & 13 & 15 & الرفاعي \\
\hline$\% 42.9$ & 5 & 43 & 12 & 11 & 0 & 4 & 1 & تل الرمان \\
\hline$\% 42.9$ & 11 & 54 & 12 & 4 & 3 & 7 & 1 & المعلمين \\
\hline$\% 57.1$ & 8 & 67 & 21 & 11 & 11 & 8 & 2 & الشهداء \\
\hline$\% 14.3$ & 1 & 9 & 13 & 2 & 0 & 1 & 0 & نابلس \\
\hline$\% 28.6$ & 3 & 8 & 12 & 4 & 11 & 2 & 0 & الرسالة \\
\hline$\% 42.9$ & 2 & 15 & 13 & 16 & 2 & 0 & 1 & العامل \\
\hline$\% 28.6$ & 2 & 39 & 7 & 2 & 11 & 0 & 0 & الطيران \\
\hline$\% 28.6$ & 11 & 26 & 8 & 5 & 8 & 0 & 0 & وادي حجر \\
\hline$\% 42.9$ & 11 & 39 & 6 & 13 & 9 & 5 & 1 & المنصور \\
\hline
\end{tabular}

* تعد العينة فاشلة وغير صالحة للشرب عند احتوائها 10 خلايا من جراثيم القولون/100مل فأكثر

تشير النتائج الى تسجيل فشل (عدم صلاحية للشرب) في عينات مياه الشرب خلال فترة الدراسة وللمناطق

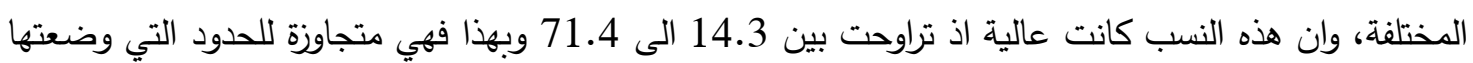
منظمة الصحة العالمية اذ ذكر كل من [16,24] ان من المعايير التي توصي بها هذه المنظمة ان لاتحتوي 95\% من عينات المياه التي يتم فحصها خلال سنة على جراثيم القولون. ويتبين من النتائج المثبتة في الجدول 
(3-3) ان هناك تبايناً في نسب الفشل من منطقة لأخرى، اذ سجلت اعلى نسبة في حي الرفاعي بلغت 71.4\%

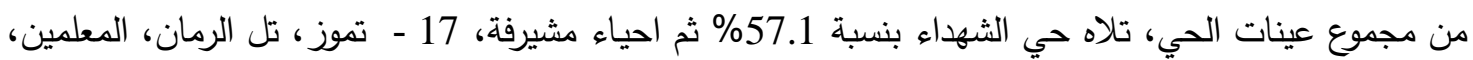
العامل والمنصور بنسبة 42.9\% لكل منها، تلتها احياء الرسالة، الطيران ووادي حجر بنسبة 28.6 \% لكل منها، فيما سجلت اقل نسبة فثل في حي نابلس اذ بلغت 14.3\%. يبين الجدول (3-4) التباين في نسب الفشل خلال اشهر الدراسة.

الجدول (4-3) اعداد جراثيم القولون الكلية /100 مل ونسب الفشل خلال اشهر الدراسة

\begin{tabular}{|c|c|c|c|c|c|c|c|}
\hline حزير ان & أيار & نيسان & آذار & شباط & كانون2 & كانون1 & أشهرالدراسة \\
\hline $\begin{array}{r}\mathrm{MPN} \\
100 \mathrm{ml}\end{array}$ & $\begin{array}{r}\text { /MPN } \\
100 \mathrm{ml}\end{array}$ & $\begin{array}{r}\text { /MPN } \\
100 \mathrm{ml}\end{array}$ & $\begin{array}{r}\text { /MPN } \\
100 \mathrm{ml}\end{array}$ & $\begin{array}{r}\text { MPN } \\
\mathrm{ml} \\
100\end{array}$ & $\begin{array}{r}\mathrm{MPN} \\
100 \mathrm{ml}\end{array}$ & $\begin{array}{c}\text { /MPN } \\
100 \mathrm{ml}\end{array}$ & \\
\hline 8 & 30 & 15 & 2 & 0 & 3 & 13 & مشيرفة \\
\hline 9 & 49 & 4 & 8 & 0 & 14 & 14 & 17- تموز \\
\hline 15 & 57 & 20 & 8 & 3 & 13 & 15 & الرفاعي \\
\hline 5 & 43 & 12 & 11 & 0 & 4 & 1 & تل الرمان \\
\hline 11 & 54 & 12 & 4 & 3 & 7 & 1 & المعلمين \\
\hline 8 & 67 & 21 & 11 & 11 & 8 & 2 & الثهداء \\
\hline 1 & 9 & 13 & 2 & 0 & 1 & 0 & نابلس \\
\hline 3 & 8 & 12 & 4 & 11 & 2 & 0 & الرسالة \\
\hline 2 & 15 & 13 & 16 & 2 & 0 & 1 & العامل \\
\hline 2 & 39 & 7 & 2 & 11 & 0 & 0 & الطيران \\
\hline 11 & 26 & 8 & 5 & 8 & 0 & 0 & وادي حجر \\
\hline 11 & 39 & 6 & 13 & 9 & 5 & 1 & المنصور \\
\hline$\% 33.3$ & $\% 83.3$ & $\% 66.6$ & $\% 33.3$ & $\% 25$ & $\% 16.7$ & $\% 25$ & بة الفشل لكل شهر \\
\hline
\end{tabular}

* تعد العينة فاشلة وغير صالحة للشرب عند احتوائها 10 خلايا من جراثيم القولون/100مل فأكثر

يتبين من النتائج المثبتة في الجدول (3-4) ان اعلى نسبة فثل سجلت في شهر أيار إذ بلغت 83.3\%، تلاه شهر نيسان بنسبة 66.7\% ثم شهري آذار وحزيران بنسبة 33.3\% لكل منهما ثم شهري كانون الأول وشباط

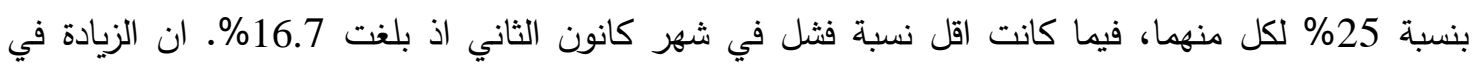
معدلات نسب الفشل المذكورة تعود لعدة اسباب من ابرزها قدم شبكة توزيع المياه وكثرة التكسرات الموجودة فيها

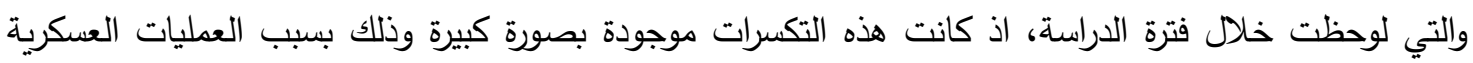
والأستعمال المغرط للقوة العسكرية الثقيلة التي رافقت عمليات تحرير الساحل الأيمن. تعد مناطق التكسرات والنضوح اماكن تدخل منها جراثيم القولون والجراثيم الممرضة الأخرى الى الثبكة خاصة وان جراثيم القولون تتواجد بصورة طبيعية في التربة والبيئة المحيطة [25,26,27]. كما ان بعض هذه التكسرات تثكل حولها حفر 
كبيرة مملوءة بالماء ترتادها الحيوانات كالأغنام والمواشي التي تكثر تربيتها في هذه المناطق، فضلاً عن الكلاب

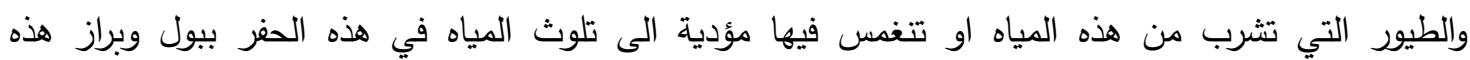

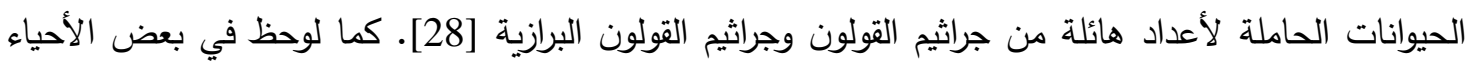

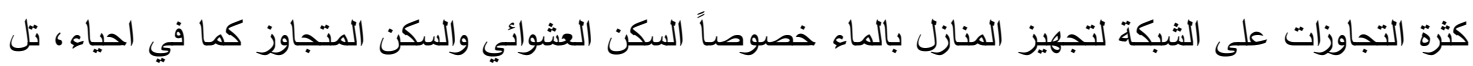
الرمان، المعلمين، الشهداء والعامل، ان هذه التجاوزات تؤدي الى حدوث تلوث في الثبكة خاصة مع استعمال

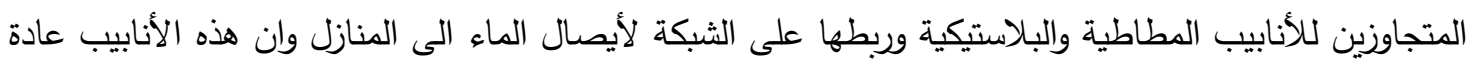
تكون مكثوفة او لايتم دفنها بصورة صحيحة مما يعرضها لكثرة التكسرات وامكانية تلوثها ببراز الأنسان والحيوانات [19]، ويعد ربط مضخات سحب المياه مباشرة على شبكة توزيع المياه في العديد من أحياء مدينة الموصل عاملاً آخراً يزيد من فرص التلوث اذ تؤدي هذه العملية الى احداث تخلخل في الضغط داخل الثبكة

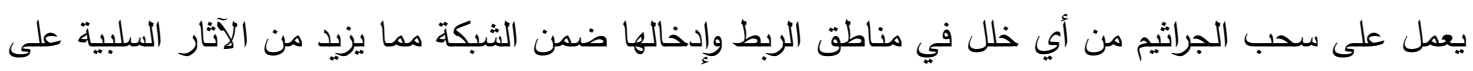

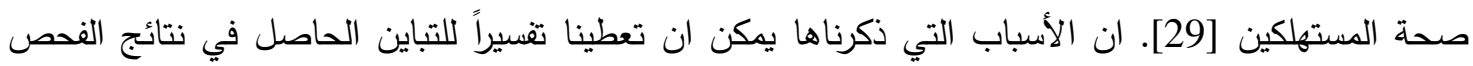

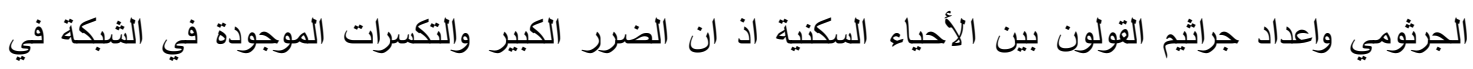

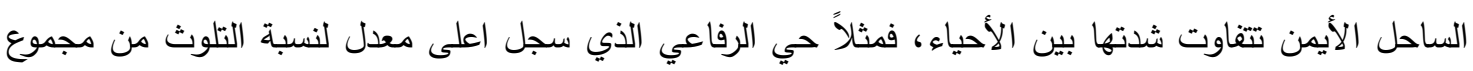

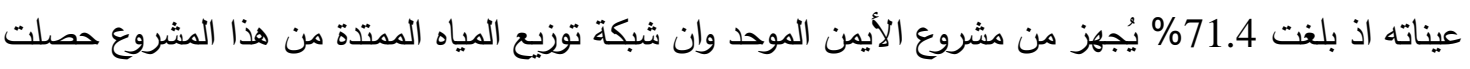

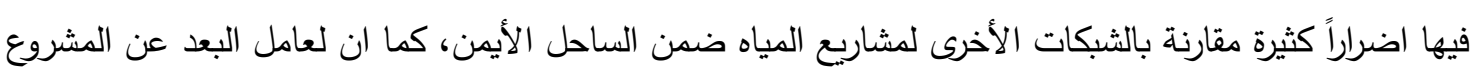

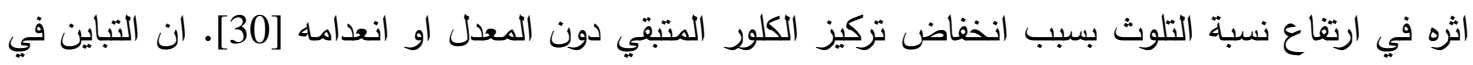
نسب الفشل خلال اشهر الدراسة مرتبط بأسباب منها تأثير درجة الحرارة على نمو الجراثيم اذ تعتدل درجات حرارة

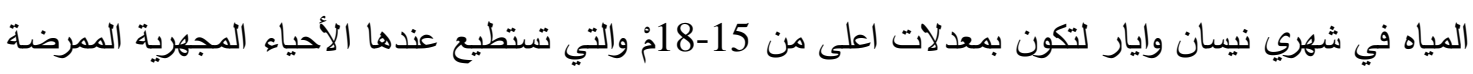

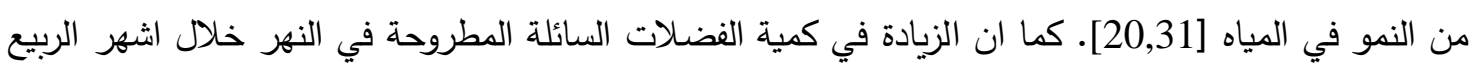
والصيف وانخفاض منسوب مياه النهر في هذه الفترة تؤدي الى زيادة التلوث العضوي والأحيائي للمياه الخام

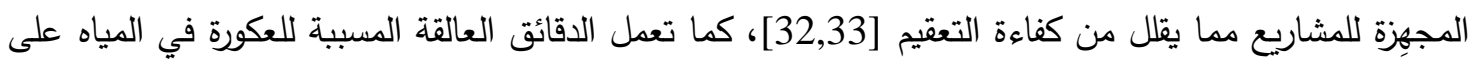

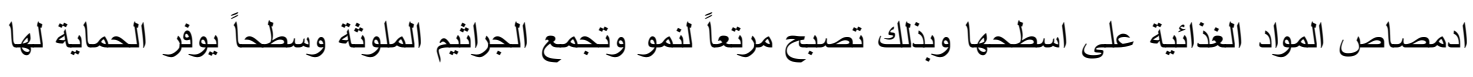
من تأثير الكلور المستعمل في عملية التعقيم من خلال الحد من تلامس الكلور مع الأغشية الخلوية للجراثيم

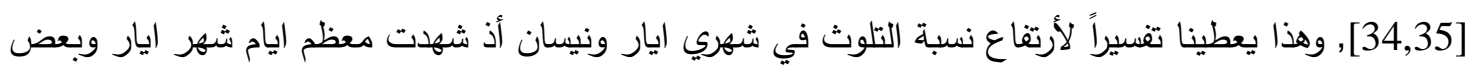
ايام شهر نيسان امطاراً غزيرة في عموم المحافظة مادى الى ارتفاع نسبة العكورة في مياه النهر نتيجة للأطيان

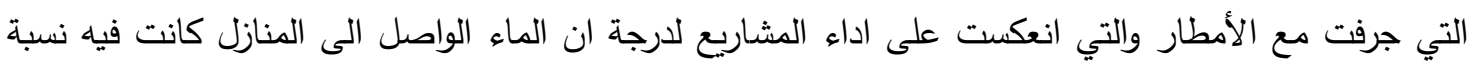

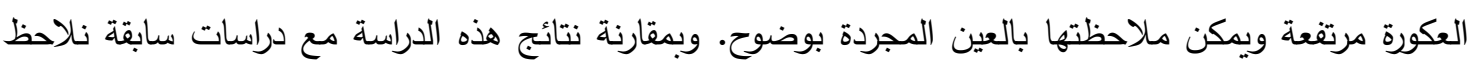

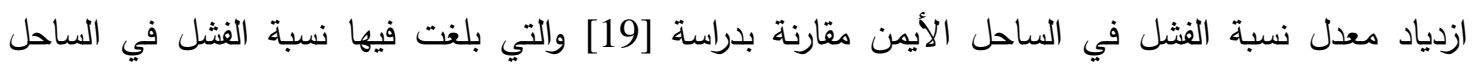

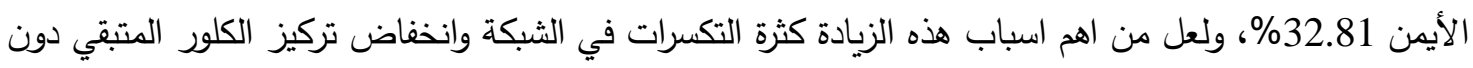
الحدود المسموح بها او انعدامه في بعض الأحيان مع ضعف الادماء مشاريع التصفية في الساحل الأيمن كما موضح في الجدول (3-1)، وبالنظر الى نتائج كل حي يمكن ان نلاحظ تقارباً في النتائج لبعض الأحياء مع الأن

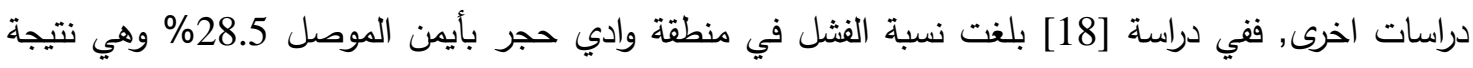

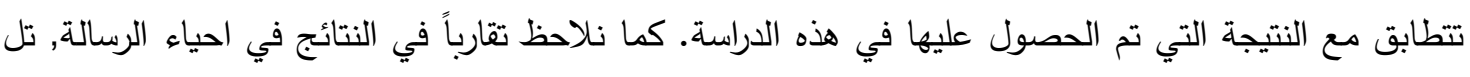

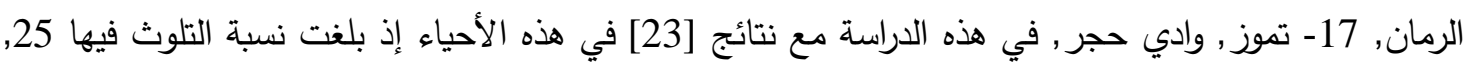

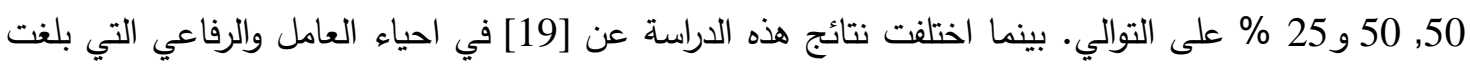


نسبة الفشل فيها 25\% لكل منهما ولعل السبب في ذلك هو انخفاض تركيز الكلور المتبقي دون الحدود المسموح بها او انعدامه في هذين الحيين ما ادى الى ارتفاع نسبة التلوث فيهما. توضح النتائج المثبتة في الجدول (3-5) العلاقة بين اعداد جراثيم القولون وتركيز الكلور المتبقي في الثبكة

اذ نلاحظ ان هناك مناطقاً كان فيها تركيز الكلور المتبقي ادنى من المعدلات المطلوبة طبقاً لما جاء في [22] 
الجدول(5-3) العلاقة بين عدد جراثيم القولون الكلية" /100 مل (MPN) وتركيز الكلور المتبقي" ملفم /لتر (Cl) في عينات مياه الثرب من مناطق الدراسة في الساحل الأيمن.

\begin{tabular}{|c|c|c|c|c|c|c|c|c|c|c|c|c|c|c|c|c|c|c|}
\hline \multicolumn{3}{|c|}{ النسبة المئوية للعينات حسبز الكلور المتبقية } & \multirow{2}{*}{ للفشل المئوية } & \multicolumn{2}{|c|}{ حزيران } & \multicolumn{2}{|c|}{ أيار } & \multicolumn{2}{|c|}{ نيسان } & \multicolumn{2}{|c|}{ آذار } & \multicolumn{2}{|c|}{ شباط } & \multicolumn{2}{|c|}{ كانون الثاني } & \multicolumn{2}{|c|}{ كانون الأول } & مناطق/أشهرالدراسة \\
\hline $\mathbf{C}$ & B & $\mathbf{A}$ & & $\mathrm{Cl}$ & $\begin{array}{c}\mathbf{M P} \\
\mathbf{N}\end{array}$ & Cl & $\begin{array}{c}\text { MP } \\
\mathbf{N}\end{array}$ & $\mathrm{Cl}$ & $\begin{array}{c}\text { MP } \\
\mathbf{N}\end{array}$ & Cl & $\begin{array}{c}\mathbf{M P} \\
\mathbf{N}\end{array}$ & Cl & $\begin{array}{c}\mathbf{M P} \\
\mathbf{N}\end{array}$ & Cl & $\begin{array}{c}\mathbf{M P} \\
\mathbf{N}\end{array}$ & $\mathrm{Cl}$ & $\begin{array}{c}\mathbf{M P} \\
\mathbf{N}\end{array}$ & \\
\hline 14.3 & 28.6 & 57.1 & 42.9 & 0.6 & 8 & 0.5 & 30 & 0.4 & 15 & 0.4 & 2 & 0.8 & $\mathbf{0}$ & 0.4 & 3 & 0.2 & 13 & مشيرفة \\
\hline 28.6 & $\mathbf{0}$ & 71.4 & 42.9 & 0.4 & 9 & 0.4 & 49 & 0.4 & 4 & 0.4 & 8 & 0.4 & $\mathbf{0}$ & 0.1 & 14 & 0.0 & 14 & 17- تموز \\
\hline 71.4 & $\mathbf{0}$ & 28.6 & 71.4 & 0.1 & 15 & 0.0 & 57 & 0.2 & 20 & 0.3 & 8 & 0.3 & 3 & 0.0 & 13 & 0.0 & 15 & الرفاعي \\
\hline 28.6 & $\mathbf{0}$ & 71.4 & 42.9 & 0.5 & 5 & 0.2 & 43 & 0.2 & 12 & 0.4 & 11 & 0.4 & $\mathbf{0}$ & 0.4 & 4 & 0.4 & 1 & تل الرمان \\
\hline 28.6 & 0 & 71.4 & 42.9 & 0.4 & 11 & 0.1 & 54 & 0.1 & 12 & 0.3 & 4 & 0.3 & 3 & 0.3 & 7 & 0.3 & 1 & المعلمين \\
\hline 57.1 & $\mathbf{0}$ & 42.9 & 57.1 & 0.3 & 8 & 0.0 & 67 & 0.0 & 21 & 0.1 & 11 & 0.0 & 11 & 0.3 & 8 & 0.3 & 2 & الشهداء \\
\hline 14.3 & $\mathbf{0}$ & 85.7 & 14.3 & 0.5 & 1 & 0.4 & 9 & 0.1 & 13 & 0.4 & 2 & 0.4 & $\mathbf{0}$ & 0.4 & 1 & \begin{tabular}{|l|}
0.4 \\
\end{tabular} & $\mathbf{0}$ & نابلس \\
\hline 14.3 & $\mathbf{0}$ & 85.7 & 28.6 & 0.4 & 3 & 0.3 & 8 & 0.0 & 12 & 0.3 & 4 & 0.3 & 11 & 0.4 & 2 & 0.4 & $\mathbf{0}$ & الرسالة \\
\hline 42.9 & $\mathbf{0}$ & 57.1 & 42.9 & 0.3 & 2 & 0.0 & 15 & 0.0 & 13 & 0.1 & 16 & 0.3 & 2 & 0.3 & $\mathbf{0}$ & 0.3 & 1 & العامل \\
\hline 14.3 & $\mathbf{0}$ & 85.7 & 28.6 & 0.5 & 2 & 0.2 & 39 & 0.5 & 7 & 0.4 & 2 & 0.4 & 11 & 0.5 & $\mathbf{0}$ & \begin{tabular}{|l|l|}
0.4 \\
\end{tabular} & $\mathbf{0}$ & الطيران \\
\hline 28.6 & 0 & 71.4 & 28.6 & 0.1 & 11 & 0.1 & 26 & 0.4 & 8 & 0.3 & 5 & 0.3 & 8 & 0.4 & $\mathbf{0}$ & 0.4 & $\mathbf{0}$ & وادي حجر \\
\hline 42.9 & 0 & 57.1 & 42.9 & 0.0 & 11 & 0.0 & 39 & 0.3 & 6 & 0.0 & 13 & 0.3 & 9 & 0.3 & 5 & 0.3 & 1 & المنصور \\
\hline 32.1 & 2.4 & 65.5 & 40.5 & & & 2 & & & & & & & & & & & & \\
\hline
\end{tabular}

A B

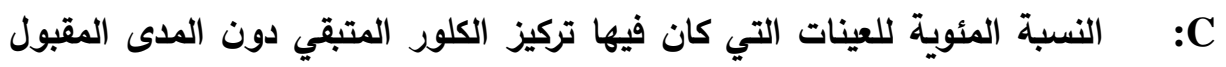

*تعد العينة فاشلة إذا احتوت على أكثر من 10 خلايا /100 مل من جراثيم القولون. *"حدت المواصفة القياسية تركيز الكلور المتبقي في الشبكة بين 0.3 بـ 0.5 ملفم/تتر. 
التي توصي بان لايقل تركيز الكلور المتبقي في نهاية الثبكة عن 0.3 ملغم/لتر شكلت هذه المناطق نسبة بلغت 32.1\%

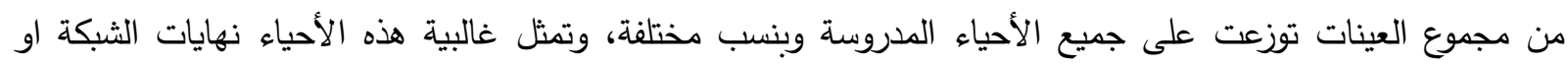

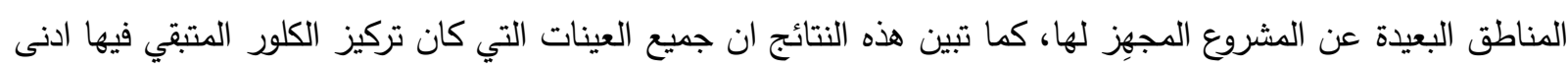

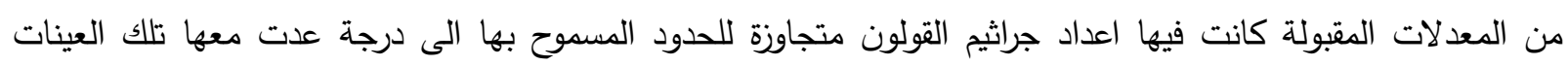
مرفوضة وغير صالحة للشرب وهذا يعطينا تفسيرا لأرتفاع نسبة الفثل في هذه الأحياء، ويدل على اهمية استعمال هذه

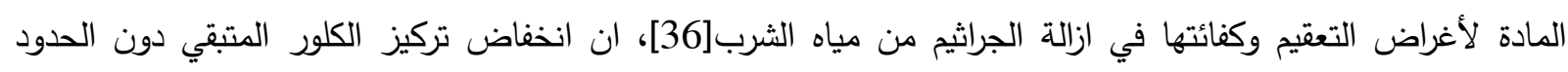

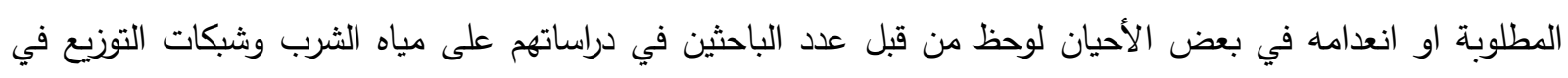

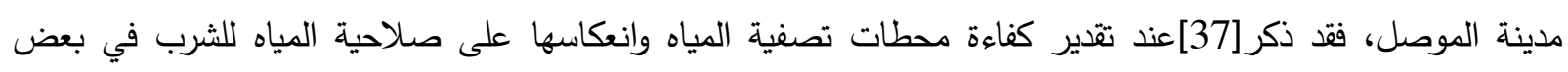

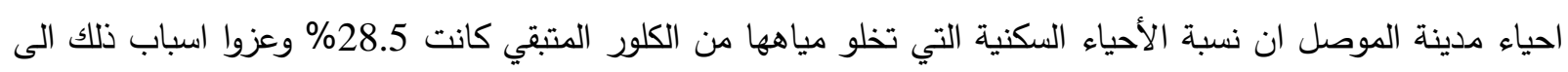
تآكل انابيب شبكة التوزيع وتسرب الملوثات اليها كما ذكرت [18] ان جميع عينات المياه التي درستها في المناطق السكنية كان فيها تركيز الكلور المتبقي دون الحدود المطلوبة وان نسبة العينات التي خلت من الكلور المتبقي بلغت

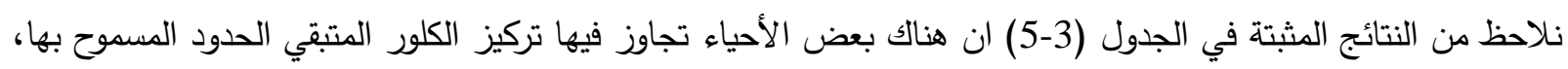

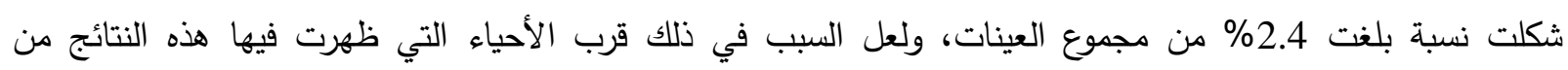

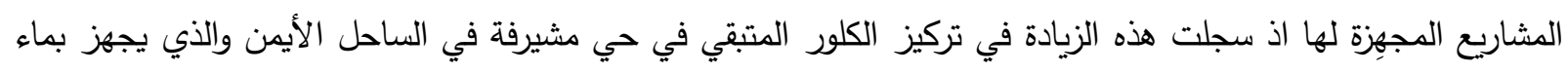

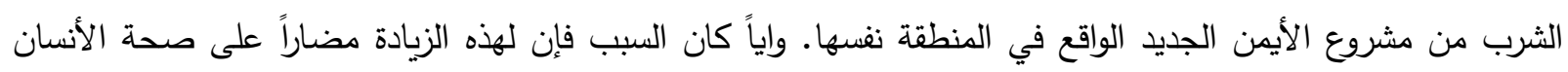

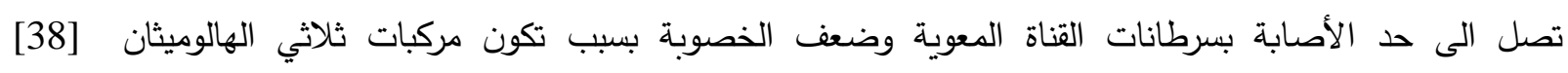
Trihalomethanes

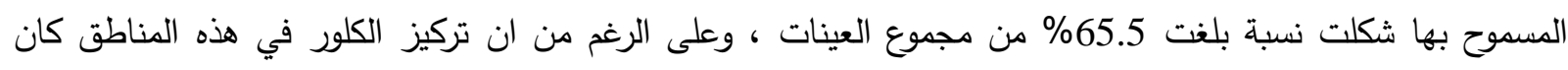

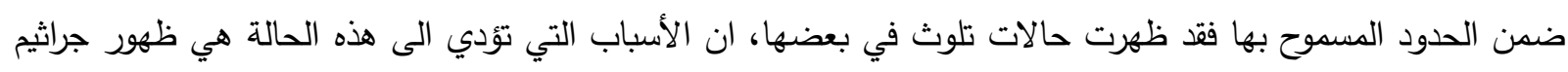

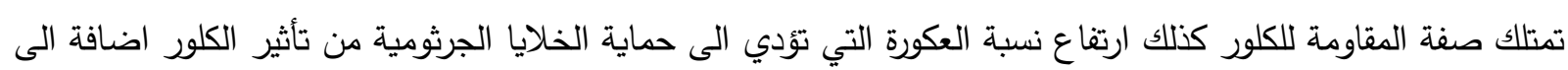
ان ارتفاع قيمة الأس الهيدروجيني داخل انابيب شبكة التوزيع تؤدي الى التأثير على فعالية الكلور في التعقيم اذ كلما

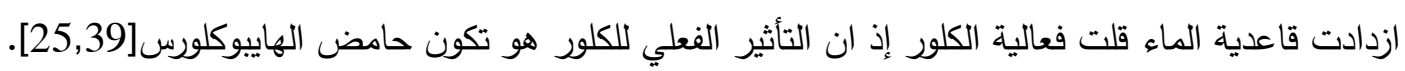

\section{* تثخيص الجراثيم الملوثة لعينات المياه}

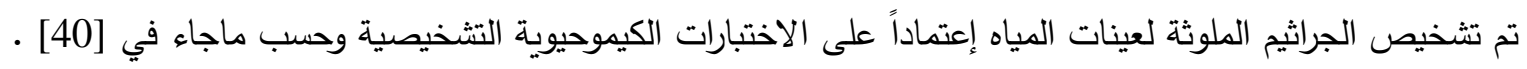
ويبين الجدول (4-1) أنواع الجراثيم المعزولة والنسب المئوية لكل جرثومة من المجموع الكلي للجراثيم المعزولة. كما يوضح الاتح الجدول (4-2) نتائج الإختبارات التثخيصية لهذه لجراثيم. 
الجدول(4-1) أعداد الجراثيم المعزولة ونسبها المئوية في عينات المياه.

\begin{tabular}{|c|c|c|}
\hline النسبة المئوية\%\% & 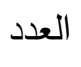 & نوع الجرثومة \\
\hline 40.8 & 20 & Escherichia coli \\
\hline 12.2 & 6 & Klebsiella pneumoniae \\
\hline 8.2 & 4 & Enterobacter cloacae \\
\hline 6.1 & 3 & Enterobacter aerogenes \\
\hline 8.2 & 4 & Proteus mirabilis \\
\hline 6.1 & 3 & Salmonella typhi \\
\hline 4.1 & 2 & Citrobacter freundii \\
\hline 14.3 & 7 & Pseudomonas aerugenosa \\
\hline$\% 100$ & 49 & Total \\
\hline
\end{tabular}

يتبين من الجدول (4-1) سيادة جرثومة E.coli ضمن جراثيم القولون المعزولة إذ بلغ عدد عزلات هذه الجرثومة 20 عزلة وبنسبة 40.8\% من مجموع الجراثيم المعزولة أن تواجد هذه الجرثومة بهذه النسبة العالية يعكس قدرتها على مقاومة الكلور المستخدم في التعقيم إذ تثير الدراسات إلى أن هذه الجرثومة تقاوم تركيز الكلور بحدود 0.31 ملغم/ لتر [41] وعزلت في هذه الدراسة جرثومة Klebsiella pneumoniae بنسبة 12.2\% وهذا يعطينا فكرة عن أهمية هذه الجرثومة في مياه Enterobacter الشرب والمشاكل الصحية والأمراض التي تسببها عند تتاول المياه الملوثة بها[26] أما جرثومتا و cloacae عدة دراسات إلى وجودهما في مياه الثرب كدراسة [19] و26] .أما جرثومة Citrobacter freundii والتي عزلت في هذه الدراسة بنسبة 4.1\% فقد عزلت هي الأخرى من مياه الشرب في الدراسات المذكورةومن الجراثيم التي عزلت في هذه الدراسة جرثومتي Salmonella typhi و وهما من الجراثيم المعوية غير المخمرة لسكر اللاكتوز عزلت الأولى بنسبة 8.2\% والأخرى بنسبة.1\% وأشارت عدة دراسات إلى وجودهما في مياه الثرب[7 , 1], وعزلت في هذه الدراسة جرثومة Pseudomonas aeruginosa بنسبة 14.3\%,هذه الجرثومة واسعة الإنتشار في البيئة الميائية وتتمو في شبكات توزيع مياه الشرب[1]. 
الجدول(4-2) نتائج الاختبارات الكيموحيوية للأنواع الجرثومية المعزولة من مياه الثرب.

\begin{tabular}{|c|c|c|c|c|c|c|c|c|c|c|c|c|c|c|c|c|c|c|c|c|}
\hline \multicolumn{4}{|c|}{ تخمر السكريات } & \multicolumn{4}{|c|}{ TSI } & \multirow{2}{*}{ 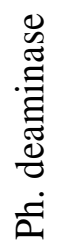 } & \multirow{2}{*}{ 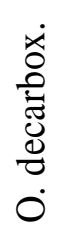 } & \multirow{2}{*}{ 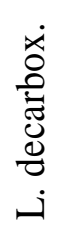 } & \multirow{2}{*}{$\overline{7}$} & \multirow{2}{*}{$\begin{array}{l}3 \\
\overline{7} \\
\overline{7}\end{array}$} & \multirow{2}{*}{$\frac{3}{3}$} & \multirow{2}{*}{3} & \multirow{2}{*}{$\begin{array}{l}\text { 多 } \\
3 \\
3 \\
3 \\
3 \\
3\end{array}$} & \multirow{2}{*}{$\frac{\text { 承: }}{\frac{1}{3}}$} & & \multirow{2}{*}{ ज़े } & \multirow{2}{*}{ 翟 } & \multirow{2}{*}{ الأاختواع/اترات / الجرثومية } \\
\hline$\overline{\overline{7}}$ & .3 & 羿 & घ) & $\frac{\bar{\Xi}}{\widetilde{\Xi}}$ & $\stackrel{\Xi}{\Xi}$ & $\frac{y}{7}$ & $\stackrel{\mathscr{I}}{I}$ & & & & & & & & & & & & & \\
\hline+ & + & + & + & A & A & + & - & - & - & + & + & - & - & - & - & + & + & - & + & E. coli \\
\hline+ & + & + & + & A & A & + & - & - & - & + & - & - & + & + & + & - & - & - & + & K. pneumoniae \\
\hline+ & + & + & + & A & A & + & - & - & + & + & + & - & - & + & + & - & - & - & + & E. cloacae \\
\hline+ & + & + & + & A & A & + & - & - & + & - & + & - & - & + & + & - & - & - & + & E. aerogenes \\
\hline- & - & - & + & $\mathrm{K}$ & A & + & + & + & + & - & + & + & + & + & - & + & - & - & + & P. mirabilis \\
\hline+ & - & - & + & $\mathrm{K}$ & A & - & + & - & + & + & + & - & - & + & - & + & + & - & + & S. typhi \\
\hline+ & + & + & + & A & A & + & + & + & - & - & + & - & - & + & - & + & - & - & + & C. freundii \\
\hline- & - & - & - & $\mathrm{K}$ & $\mathrm{K}$ & - & - & - & - & - & + & - & - & + & - & - & - & + & + & $\begin{array}{c}\text { Pseudo. } \\
\text { aerugenosa }\end{array}$ \\
\hline & & & & & & & & & c & & & & & & & & & & & \\
\hline
\end{tabular}




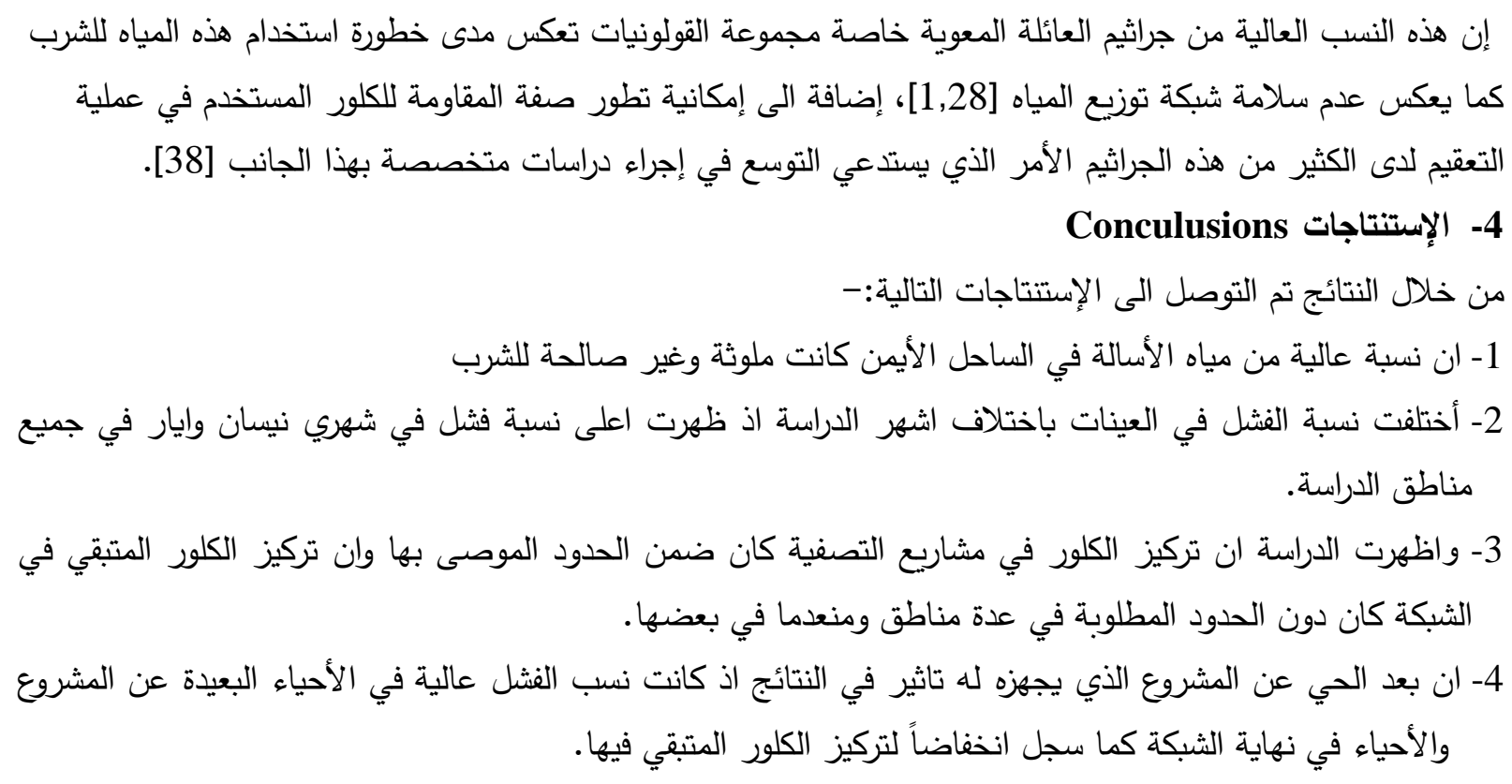

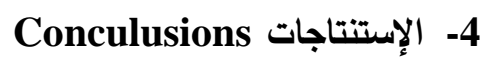
من خلال النتائج تم التوصل الى الإستنتاجات التالية:-

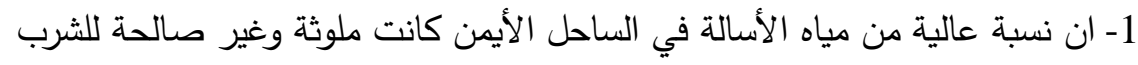
2- أختلفت نسبة الفثل في العينات باختلاف اشهر الدراسة اذ ظهرت اعلى نسبة فثل في شهري نيسان وايار في جميع مناطق الدراسة. 3- واظهرت الدراسة ان تركيز الكلور في مشاريع التصفية كان ضمن الحدود الموصى بها وان تركيز الكلور المتبقي في الثبكة كان دون الحدود المطلوبة في عدة مناطق ومنعدما في بعضها.

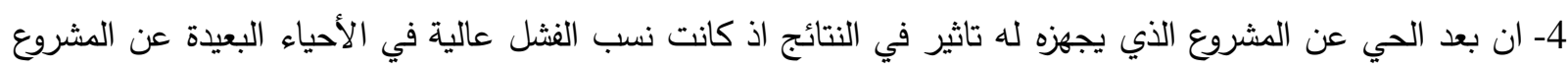
والأحياء في نهاية الثبكة كما سجل انخفاضاً لتركيز الكلور المتبقي فيها.

\section{Recommendations 5 التوصيات}

1- دراسة اسباب التلوث الجرثومي لمياه نهر دجلة ووضع المعالجات والحلول لمنع هذا التلوث. 2- تطوير مشاريع التصفية وشبكات توزيع المياه والأرتقاء بها الى مستوى المواصفات العالمية.

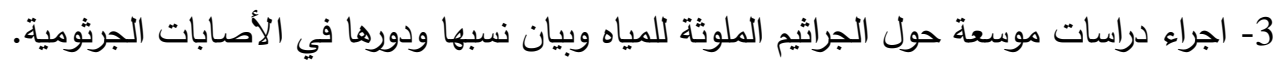
4- استعمال الطرائق الجزيئية للتحري عن الداثلائل الجرثومية لتلوث المياه 5- اجراء دراسات حول امكانية استعمال بعض المركبات المضادة للجراثيم كبدائل عن الكلور في التعقيم.

Acknowledgment-6 تم إجراء جميع الأختبارات المتعلقة بهذا البحث في مختبر بحوث الأحياء المجرية / قسم علوم الحياة / كلية التربية للعلوم الصرفة / جامعة الموصل.

References: المصادر

1- Nath, K.J.; Bloomfield, S. and Jones, M., "Household water storage handing and Point of use treatment". International Scientific Forum on Home Hygiene (IFH). USA. (2006).

2- Al-Tomei, A.S. and Saad, M.A., "Bacteriology Of Drinking Water". Biotechnic Research Center (2008).

3- Ayandrian, T.A.; Fawole, O.O. and Dahunsi, S.O., Water resour. and indus. Jour. 19: 13-24(2018).

4- EOC. Yemen cholera response. Emergency Operation Center, Situation report No.11 (2017).

5- Nishiura, H.; Tsuzuki, S.; Yuan, B.; Yamaguchi, T. and Asai, Y., Theoretical biology and medical modelling. 14(2017).

6- Al-Nazal, A.A. ; Hussein, A.A. and khalil, Y.A., Al- Anbar Univer. Jour. For Pure Science, 3(3): 1-7 (2009). 
7- Skipton, S.O.; Dvorak, B.I.; Woldt, W.E. and Wirth, S.L., "Drinking Water: Bacteria". Institute of Agriculture and Natural Resources, Lincoln Extension, University of Nebraska (2014).

8- WSDH. "Coliform bacteria and drinking water" . Washington State Department of Health, division of environmental health, office of drinking water (2016).

9- WDONR. "Bacteriological contamination of drinking water wells". Wisconsin Department Of Natural Resources, Bureau of drinking water and ground water. Washington, D.C (2017)..

10- Nollet, L.M.L. "Handbook of water analysis". $2^{\text {nd }}$ ed., CRC press, London. UK (2007).

11- Talaro, K.P. and Chess, B., "Foundations in Microbiology", $9^{\text {th }}$ ed. McGraw-Hill Education, 2 Penn Plaza, New York (2015).

12- Black, J.G., "Microbiology: Principles and Explorations", $8^{\text {th }}$ ed. John Wiley \& Sons, Inc., U.S.A (2012). .

13-Kumar, D.; Malik, S.; Madan, M.; Pandey, A.; Asthana, A.K., IOSR Jour. of Environ. Scien., Toxicology and food techn., 4(3): 17-22 (2013).

14- APHA. "Standard Method for Examination of water and wastewater". American Public Health Association, 20 $0^{\text {th }}$ ed., Washington DC, USA (1998).

15- Abbawy, S.A. and Hasan, M.S., " Practical Engineering Of Environment - Water analysis'. Dar Al- Hekma for Priting and Publishing, Mosul-Iraq (1990).

16- Antony, R.M. and Renuga, F.B., An Interdisciplinary Jour. Of Appli. Scien., 7(2) : 4248 (2012).

17- Hammer, Mark J. ; Hammer J. and Mark J., "Water and Wastewater Technology". $5^{\text {th }}$ ed., New Jersey (2004).

18- Al-Nua'aemy, M.M.M., Msc. Thesis,College Of Scince, University Of Mosul, Iraq (2017). (In Arabic).

19- Al-Oqaidy, A.J.A., Msc. Thesis, College Of Scince, University Of Mosul, Iraq (2009). (In Arabic).

20- Bitton, G., "Wastewater Microbiology". $3^{\text {ed }}$ ed., John Wiley \& Sons, Inc. Hoboken, New Jersey (2005).

21- Razuki, S. M.M. and AL-Rawi, M.A., Iraq. Jour. For Market Res. and Consumerism 2(4): 98-129 (2010).

22- Iraqi Regularity Standers Of Drinking Water No.417, $2^{\text {nd }}$ modernnization, Central System for Standerization and Qualitative Control, Ministary of Planing and Development cooperation. Iraq(2009).

23- Payment, P.; Sieniatycki, J.; Richardson, L.; Renand, G.; France, E. and Prevost, M. Internat. Jour. Of Environ. Health Res., 7: 5-31 (1997).

24-Sami, Z. and Abdul Ghafoor, M.A.K., JPMA 38: 92-96 (1988).

25- Hasan, B.K.; Abdulrazaq, S.and Rasheid, A., The Tech. Jour., 3:76-84(1997).

26- Prasai, T.; Lekhak, B.; Joshi, D.R. and Baral, M.P.,.Scient World, 5(5):112-114 (2007).

27- MDH. "Coliform bacteria in drinking water". Minnesota Department of Health, Drinking water Protection Section (2016).

28-Shartoh, S.M.; Hammadi, A.H.; Hasan, R.K.; Abdulmaged, A.A. and Sallom, B.H., Bagh. Jour. For Scien., 8(3): 243-247(2011).

29- Al- Ta'ei, N.D.S., Msc. Thesis,College Of Education, University Of Mosul, Iraq (2011) (In Arabic).

30- Alia, T., Teshrein Univer. Jour. For Stud. and Scient. Res.- Engin. Scien. Series, 29(2): 1-13(2007).

31- Sigee, D.C., "Freshwater Microbiology". John \& Sons, LTD. England (2005). 
32- Al- Sngry, M.N. and Al-Mashhadany, Y.D., $1^{\text {st }}$ Scienti. Conf. Of Environ. Res. and Poll. Contr., University Of Mosul, Iraq (2007).

33- Al- Saffawi, A.Y.T., Al- Utroha Jour. For Environ. Scien., 5:13-25(2018).

34-Khalaf, S.H., "Aquatic Microbiology", Dar Al- Kotob for Priting and Publishing, College Of Scince, University Of Mosul, Iraq(1987).

35- Perice, J.J.; Weiner, R.F. and Vesilind, P.A. "Environmental pollution and control". $4^{\text {th }}$ ed. McCGraw-Hill Book Company, New York(1998).

36-WHO., "Water Treatment and pathogen control process deficiency in achieving safe Drinking water", $8^{\text {th }}$ ed. published by IWA, London. UK(2004).

37-Mohammad, M.A. and Hamid, S.L., $1^{\text {st }}$ Scienti. Conf. Of College Of Environmental Sceinces and It's University Of Mosul, Iraq(2009).

38-Gang, D.; Clevenger, T. E. and Banerji, S.K.,. Jour. Of Hazardous Materiales, 96:1-12 (2003).

39- Al-Jelawi, S.F., Karbala Univer. Jour., 2(6): 109-121(2004).

40-Procop, G.W.; Church, D.L.; Hall, G.S.; Janda,W.M.; Koneman, E.W.; Schreckenberger, P.C.; and Woods, G.L.. Koneman's color atlas and textbook of diagnostic microbiology. $7^{\text {th }}$ ed. Wolters Kluwer Health, Philadelphia (2017).

41- Al-Azawi, A.H.S., Msc. Thesis, College Of Scince, University Of Mosul, Iraq (1998). (In Arabic) 